\title{
Why Science Standards are Important to a Strong Science Curriculum and How States Measure Up
}

\author{
Louise S. Mead • Anton Mates
}

Published online: 7 August 2009

(C) Springer Science + Business Media, LLC 2009

\begin{abstract}
In 2000, Lawrence Lerner and the Thomas B. Fordham Foundation reviewed state science standards in 49 states and the District of Columbia, specifically with respect to the coverage of evolution. We repeat his survey for all current standards publicly available as of May 2009 and discuss the history and role of state science standards in American public education. Our survey indicates that science standards tend to cover evolution more extensively than they did a decade ago, and that the average quality of the treatment has increased. However, certain types of creationist language are also becoming more common in state standards. We also discuss the history and role of state science standards in American public education.
\end{abstract}

Keywords Science curriculum · States · Standards · Evolution

\section{Introduction}

When it comes to state science standards and evolution, we at the National Center for Science Education sit up and take notice, for there is perhaps no other arena in which the religious controversy surrounding evolution plays out to such a detrimental degree as in the generation of poor science standards. Local and state control of education can lead to state science standards that reflect political and religious agendas, rather than good pedagogy and strong science. Texas is an excellent example, where recent amendments to the Texas Educational Knowledge and

L. S. Mead $(\square) \cdot$ A. Mates

National Center for Science Education,

PO Box 9477, Berkeley, CA 94709-0477, USA

e-mail: mead@ncseweb.org
Skills (TEKS) document now require the presentation of creationist claims about the complexity of the cell, the completeness of the fossil record, and the age of the universe, despite calls from over 50 scientific and educational societies to support accurate science education by adopting the science standards as originally written by scientists and educators on the writing committee (Simon 2009). Any study of biological, earth, and space sciences must place evolution in its rightful place, as "the foundation of modern biology" and crucial to fields as diverse as agriculture, astronomy, computer science, engineering, geology, and medicine (A Message to the Texas State Board of Education 2009). Yet, in Texas and around the country, the inclusion of evolution in state science standards continues to be challenged and marginalized. But does it matter? Do science standards actually play an important role in curriculum, science education, and scientific literacy with respect to evolution? And if so, how do states measure up?

\section{Part I. History and Role of State Science Standards}

The USA has a long history of preferring local over state control of education. By the early 1980s, however, reports clearly indicated that the USA was falling behind other nations in educational benchmarks, and in particular, science literacy. In A Nation at Risk: The Imperative for Education Reform, the National Commission on Excellence in Education (1983) called for strengthening public education by implementing higher expectations, specifically recommending "schools, colleges, and universities adopt more rigorous and measurable standards." Since then, all states and the District of Columbia have acquired some form of state science standards. National organizations have also chimed in, offering model standards. The American 
Association for the Advancement of Science founded Project 2061 in 1985, publishing two significant works to guide scientific literacy: Science for All Americans (American Association for the Advancement of Science 1989) and Benchmarks for Science Literacy (American Association for the Advancement of Science 1993). The National Research Council's (1996) National Committee on Science Education Standards and Assessment also developed National Science Education Standards in 1996.

The process of generating state science standards varies from state to state. Often, the state department of education assembles a committee of scientists, teachers, parents, and others to write and/or revise earlier standards. In some cases, state school boards get involved in the process, as occurs in Texas, which has the unfortunate effect of placing elected officials, with little or no knowledge or expertise in the fields whose curricula they govern, responsible for approving standards written by experts. In theory, states seek to adopt standards that represent what scientists and practicing educators deem important for scientific literacy. For example, with respect to evolution, Skoog and Bilica (2002) make it clear that science standards should "emphasize evolution in a manner commensurate with its importance in understanding the natural world and our place within it." In practice, however, the coverage of evolution in science standards can be less than adequate, not because the topic is scientifically controversial but because officials either have a specific religious agenda or don't want to "ruffle creationist feathers" (Lerner 2000).

According to Lerner (2000), standards are "meant to serve as the frame to which everything else is attached," forming the foundation for curricular activities and driving "standards based" educational reform (Lerner 2000). For example, California has curriculum frameworks and instructional materials designed specifically to provide guidance for implementing the content standards. There are websites, such as Understanding Evolution (http:// berkeley.edu/evolution), that allow teachers to search for lesson plans that correspond to particular sections of their state's science standards. Statewide exams administered at specific grade levels are also designed to reflect state standards. For example, in New York, the Regents Examination in Living Environment is designed to provide a measure of 'students' attainment of the New York State Learning Standards in Science, as defined by the New York State Learning Standards for Mathematics, Science, and Technology." Finally, publishers shape the content of their textbooks according to the standards of some of the larger states (Lerner 2000), even issuing special editions for use in the larger states such as Texas, California, and Florida. The Texas edition of Holt Biology, for example, features the state reptile (the horned lizard, Phrynosoma cornutum) on its cover and contains "Texas BioWatch" boxes that "describe scientific research being carried out in Texas today"; the teacher's edition, moreover, provides information about how the content connects with the TEKS and the Texas Assessment of Knowledge and Skills (TAKS) tests (Johnson and Raven 2004: xvi).

Unfortunately, even if state science standards accurately reflect the central role of evolution in biology, there is no guarantee that evolution will be taught effectively. Moore (2009) noted that supposedly state science standards are the basis for what teachers teach and students learn and thereby establish the foundation for states' desired education outcomes. However, Moore also found little correlation between good science standards, particularly with respect to evolution, and instruction in evolution by biology teachers. Regardless of how a state measures up with respect to the inclusion of evolution in the state science standards, the percentage of teachers believing that creationism should be taught in science classes in public schools varies little (Moore 2009). Comments like "evolution is indeed difficult to teach in my biology classes...due to the lack of scientific evidence for many of its claims" are made by teachers even in states with strong science standards. Good science standards do not seem to be correlated with good science teaching.

We therefore return to the primary question: Are standards really that important and/or effective when it comes to improving evolution education? Does it really matter, for example, that some states describe evolution only as "change through time" rather than as descent with modification from a common ancestor? The answer is "Yes." Even if a good treatment of evolution in state science standards does not guarantee that evolution will be taught well, it provides a critical resource for teachers who want to teach evolution correctly. The clearest example is that a good treatment of evolution in the standards provides important support for biology teachers facing protests from creationist students, parents, and administrators who want creationism taught, or evolution not taught, in life science courses. However, it is also an important support for combating two other problems, experienced by many science teachers who contact NCSE for advice: parents who want their students to be able to "opt out" from evolution-related lessons and creationist teachers of nonscience subjects who attack evolution in their own classes. Both of these phenomena have the same educational impact as attacks on or omission of evolution in science class; they leave students ignorant or misinformed about evolution. However, administrators often deal with the latter situations differently, reasoning that if science teachers are not actually being prevented from teaching as they deem appropriate, it is best to keep everybody happy by allowing creationist students to opt out and other teachers to criticize evolution if they want to. A good treatment of evolution in 
state science standards can help to persuade administrators that the teaching of evolution is not a matter for political negotiations between parents and teachers with different interests but a clear educational necessity. Students simply should not be allowed to opt out of material that the state considers essential (Scott and Branch 2008), and nonscience teachers should not be allowed to contradict or undermine this material in their own lessons.

\section{"Creationist Jargon"}

So how is evolution faring in today's state science standards? There is, thankfully, no explicit requirement that creationism be taught or evolution not be taught in any of the state science standards currently in force. However, that is not altogether comforting, for in general, over the last two decades, creationists have reduced their advocacy of state-level legislation and policy that explicitly endorse creationist claims or attack evolution. Blanket bans on evolution and policies requiring "balanced treatment" of evolution and creationism have given way to more innocuous language, such as "teaching the controversy," "critical analysis," "strengths and weaknesses," "academic freedom," and "discussing the full range of scientific views" (Branch and Scott 2009). This is doubtless largely because such attempts have been obstructed by the courts at every turn, but it also reflects a growing creationist understanding that such legislation is not necessary to accomplish many of their goals in the public schools. Most creationism advocates in America are members of likeminded communities, which provide them with ready access to any amount of antievolution material - textbooks, articles, and video programs. Hence, there is no need to recycle or even refer specifically to this material in government policies. An antievolution policy need merely implicitly permit such material to be taught, and creationist pressure at the local level will often ensure that it is taught. Indeed, creationist legislators themselves have frequently made this point. In 2004, the first "academic freedom" bills were introduced in Alabama; Senate Bill 336 and House Bill 391 would have permitted teachers "to present scientific, historical, theoretical, or evidentiary information pertaining to alternative theories or points of view on the subject of origins." No explicit mention was made of creationism or any standard creationist claims. Nonetheless, a sponsoring state representative explained that "Evolution is one theory, creation is an alternative theory," while the lead senate sponsor said that his bill "allows a teacher to bring forward the biblical creation story of humankind." (Montgomery Advertiser, February 18, 2004). Similarly, the original text of 2008's Louisiana Science Education Act (enacted as Louisiana Revised Statutes 17:285.1) encouraged teachers to "help students understand, analyze, critique, and review in an objective manner the scientific strengths and scientific weaknesses of existing scientific theories pertinent to the course being taught." Elsewhere in the bill, evolution was listed as one such theory. In the finalized bill, this was trimmed to "help students understand, analyze, critique, and review scientific theories in an objective manner." The sponsoring senator explained that this act would permit the discussion of "scientific data related to creationism" (Hammond Daily Star, April 6, 2008).

It is therefore important when reviewing the treatment of evolution in state science standards to bear this shift in creationist strategy in mind. Whereas Lerner (2000:13) defined "creationist jargon" as the kinds of language used by creationists to cast doubt on the theory of evolution, we define it also to include the kinds of language used by creationists to justify the use of teaching material that casts doubt on the theory of evolution. The aforementioned Alabama and Louisiana bills exemplify two general strains of such language. The first strain emphasizes the supposed weaknesses of evolution - the phrase "strengths and weaknesses," as in the Louisiana bills, is common-and the existence of supposedly scientific credible alternatives to evolution. Creationism is typically not mentioned among the alternatives, but it is also typically not explicitly included: The Alabama bills referred only to "alternative theories or points of view" or, as in their successors in 2005, House Bill 352 and Senate Bill 240, "the full range of scientific views." Such language does not necessarily explicitly endorse creationist viewpoints. It need not explicitly state that there are scientifically credible alternative theories to evolution, let alone what those theories might be. It need not assert that a significant section of the scientific community has challenged the validity of evolution or that evolution definitely has "weaknesses." However, it permits and encourages the teaching of material that would do all of these things - and in the USA, at least, such material is inevitably creationist. This language, moreover, is misleading as it stands. It is simply not true that there are credible scientific alternatives to evolution, nor that evolutionary theory has "weaknesses" that make it unlikely to be true, nor that scientific work has been done that casts doubt upon it. Students should be left in no doubt on this score. As the National Science Teachers Association observes in its position statement on the teaching of evolution, "Scientific disciplines with a historical component, such as astronomy, geology, biology, and anthropology, cannot be taught with integrity if evolution is not emphasized. There is no longer a debate among scientists about whether evolution has taken place."

A second strain of creationist language is perhaps more dangerous because it is more subtle. This strain directs the student to judge the validity of evolution - to "critique," 
"assess," or "evaluate" it. The Louisiana Science Education Act over-egged the pudding by urging teachers to help their students to "understand, analyze, critique, and review scientific theories in an objective manner."

To many Americans, this seems harmless or even laudable - why shouldn't students practice evaluating the scientific theories they study? Of course, the answer is that students should do so-but only in a way that will in fact promote their understanding of science and that is otherwise pedagogically responsible. In the case of Louisiana, there is certainly reason to think that, on the contrary, evolution will be invidiously singled out for attention and that creationist critiques of evolution will be used. When Louisiana's Board of Elementary and Secondary Education adopted a policy about what types of supplementary classroom materials will, and will not, be allowable under the new law, a draft provision that "materials that teach creationism or intelligent design... shall be prohibited from use in science class" was deleted (Rosenau 2009).

The aspiration to have middle and high school students evaluate evolutionary theory, moreover, is not entirely realistic from a pedagogical perspective. Students should evaluate the scientific theories they study-but not before they fully understand those theories! As the foundation to the entire science of biology, evolutionary theory is vast and complex, resting on a variety of evidential bases from a number of scientific fields-all of which students are generally being introduced to for the first time in high school. Students will not finish learning about it in detail until, at minimum, their later years of college, and they will not begin seriously analyzing it and synthesizing their knowledge until graduate school. Expecting high school biology students to be able to evaluate evolutionary theory is no more reasonable than expecting high school physics students to evaluate quantum field theory. If students had the necessary knowledge and skills to make such judgments, there would be little reason for college science courses! Thus, the language we classify as "creationist jargon" is pedagogically unsound in and of itself, gives license to the use of creationist teaching materials, and is known in several cases to have been introduced by creationist legislators and policymakers for precisely this purpose.

\section{Part II. How States Measure Up}

State science standards have been formally reviewed twice, by Braden et al. (2000) and Gross et al. (2005). Lerner (2000) also provided a comprehensive evaluation of the treatment of evolution in state science standards, as did Swanson (2005), following a different methodology. Many states have revised their standards since the publication of these reviews. Using Lerner's (2000) criteria (Table 2 Appendix), we re-evaluated and graded all state science standards (or comparable documents - see Table 3 Appendix for a complete list) - in all 50 states and the District of Columbia specifically on their inclusion and coverage of evolution; and we report results here (Table 1, Fig. 1; and Table 2 Appendix).

Forty-seven states and the District of Columbia have revised their state science standards since Lerner (2000), with only California, Nebraska, and New York still working with standards written before 2000. Twenty-four states have revised (or are in the process of revising as is the case with Colorado and Minnesota) their science standards in the last four years. The good news is that, in our re-evaluation, nine states and the District of Columbia receive a grade of $\mathrm{A}$, indicating that the treatment of evolution is excellent or very good. Five states, however, fail in their treatment of evolution. In these cases, the treatment of evolution is absent or made useless by the inclusion of creationist jargon and/or disclaimers. The remainder of the states are more equally distributed: 16 states score in the $\mathrm{B}$ range, 14 score in the $\mathrm{C}$ range, and only six in the $\mathrm{D}$ range. Our survey indicates only 11 states total have standards with unsatisfactory treatment of evolution.

A comparison of current grades with those assigned by Lerner (2000) appears in Table 1. Fourteen states and the District of Columbia show some improvement in their state science standards with respect to the treatment of evolution. Twenty-five states showed no change in their grades from 2000. Five of these received grades of D or worse, and perhaps more importantly, each made revisions to science standards in the intervening years since Lerner (2000) published his report indicating each state's unsatisfactory or failing treatment of evolution. Ten states show a decline in their grade, in most cases because specific and clear treatment of human evolution was either omitted or dropped from the standards.

In following the criteria set out by Lerner (2000), we evaluated the inclusion of not only biological evolution but also geological evolution, cosmology, and treatment of the connection among the life, earth, and space sciences. Table 3 in Appendix shows the specific scores for each state in each area evaluated as well as some general comments. The treatment of biological evolution in state science standards has improved dramatically over the last ten years. We consider this great news! Only Alabama dropped in the score for biological evolution. Other areas show less consistent trends in treatment. As noted above, treatment of human evolution is abysmal. Only seven states and the District of Columbia provide a comprehensive treatment of human evolution. Geological evolution and cosmology are also variously treated. In general, inclusion of geological evolution is better and more consistent than 
Table 1 Grades and general comments for treatment of evolution in state science standards

\begin{tabular}{|c|c|c|c|}
\hline State & $\begin{array}{l}\text { Grade Lerner } \\
(2000)\end{array}$ & $\begin{array}{l}\text { Current } \\
\text { Grade } 2009\end{array}$ & Description and/or general comments. \\
\hline Alabama & $\mathrm{F}$ & $\mathrm{F}$ & General coverage of evolution is poor. Evolution disclaimer in the Preface \\
\hline Alaska & $\mathrm{D}$ & $\mathrm{D}$ & $\begin{array}{l}\text { Treatment of biological evolution is adequate. Human evolution is not covered, nor is the } \\
\text { connection between biological, geological and cosmological evolution }\end{array}$ \\
\hline Arizona & $\mathrm{B}$ & $\mathrm{B}$ & Direct treatment of evolution does not occur until high school and human evolution is not covered \\
\hline Arkansas & $\mathrm{D}$ & $\mathrm{C}$ & $\begin{array}{l}\text { Improved treatment of biological evolution. No coverage of human evolution. No earth or space } \\
\text { science at all at the high school level }\end{array}$ \\
\hline California & A & A & Comprehensive treatment of evolution. Human evolution is presented in 6th grade social studies \\
\hline Colorado & $\mathrm{B}$ & $\mathrm{B}$ & $\begin{array}{l}\text { Discussion of evolution is good (but see Part II: Colorado for more details). No mention of Big } \\
\text { Bang }\end{array}$ \\
\hline Connecticut & A & $\mathrm{D}$ & $\begin{array}{l}\text { Human evolution has been dropped. Despite specific reference to evolution in PreK- } 8 \text { framework, } \\
\text { there is no mention of age of the earth, fossils, Big Bang theory, plate tectonics, etc. }\end{array}$ \\
\hline Delaware & A & $\mathrm{B}$ & $\begin{array}{l}\text { Good treatment of evolution. No explicit reference to human evolution. Some language is } \\
\text { vulnerable to exploitation or misinterpretation. (e.g., A recurring "Essential Question" in the } \\
\text { "Earth in Space" standard is, "Is there an order to the Universe? Explain.") }\end{array}$ \\
\hline $\begin{array}{l}\text { Dist. Of } \\
\text { Columbia }\end{array}$ & $\mathrm{B}$ & A & Treatment of evolution has improved; human evolution is explicit \\
\hline Florida & $\mathrm{F}$ & A & Greatly improved \\
\hline Georgia & $\mathrm{F}$ & $\mathrm{C}$ & $\begin{array}{l}\text { Human evolution mentioned in the Anatomy and Physiology standards, but not in the life science } \\
\text { standards }\end{array}$ \\
\hline Hawaii & A & $\mathrm{C}$ & Wording in the Earth and Space Science standards includes creationist jargon \\
\hline Idaho & $\mathrm{B}$ & $\mathrm{B}$ & $\begin{array}{l}\text { Human evolution is not covered. "Understand the Theory of Biological Evolution" assessed as } \\
\text { "Describe how natural selection explains species change over time" and does not include any } \\
\text { reference to common ancestry }\end{array}$ \\
\hline Illinois & $\mathrm{D}$ & $\mathrm{B}$ & $\begin{array}{l}\text { Review included evaluation of descriptors - which now include the word "Evolution". No explicit } \\
\text { reference to specific geological and cosmological evolution terms, although concepts covered }\end{array}$ \\
\hline Indiana & A & A & Good \\
\hline Iowa & & $\mathrm{C}$ & $\begin{array}{l}\text { Iowa Core Curriculum is new. } 2008 \text { legislation requires all school districts to implement Iowa } \\
\text { Score Curriculum by } 2012 \text { for grades } 9-12 \text { and } 2014-2015 \text { for K-8 }\end{array}$ \\
\hline Kansas & F- & A & After various battles with the state school board, standards have improved immensely \\
\hline Kentucky & $\mathrm{D}$ & $\mathrm{D}$ & $\begin{array}{l}\text { E-word used minimally; some biological evolution covered; no human evolution. Cosmology very } \\
\text { limited }\end{array}$ \\
\hline Louisiana & $\mathrm{C}$ & $\mathrm{F}$ & $\begin{array}{l}\text { Louisiana Science Education Act includes creationist jargon and disclaimers which nullify much } \\
\text { of the science standards in reference to evolution }\end{array}$ \\
\hline Maine & $\mathrm{F}$ & $\mathrm{C}$ & $\begin{array}{l}\text { Adequate treatment of basic biological evolution; no human evolution; minimal treatment of } \\
\text { geological, cosmological and historical interfaces-e.g. plate tectonics not mentioned until high } \\
\text { school }\end{array}$ \\
\hline Maryland & $\mathrm{C}$ & $\mathrm{C}$ & No human evolution. Discussion of cosmology in earth and space standards lacking \\
\hline Massachusetts & $\mathrm{B}$ & $\mathrm{B}$ & $\begin{array}{l}\text { Mention of human evolution is disguised. Discussion of cosmological evolution does not occur } \\
\text { until high school }\end{array}$ \\
\hline Michigan & B & $\mathrm{B}$ & Cosmology and historical connection could be stronger \\
\hline Minnesota & $\mathrm{B}$ & $\mathrm{B}$ & $\begin{array}{l}\text { Generally good, however, standards continue to contain passage originally intended to forestall } \\
\text { creationist objections }\end{array}$ \\
\hline Mississippi & $\mathrm{F}$ & $\mathrm{B}$ & Evaluated 2010 Science Framework, revised 2008. Clear improvement over previous versions \\
\hline Missouri & $\mathrm{B}$ & $\mathrm{C}$ & $\begin{array}{l}\text { No human evolution. Students are expected to be able to "identify and analyze theories that are } \\
\text { currently being questioned, and compare them to new theories that have emerged to challenge the } \\
\text { older ones." The practice of exposing students to unresolved questions in modern science is a } \\
\text { worthy one, but care must be taken that the topics covered do in fact represent legitimate areas of } \\
\text { current scientific debate, and that this debate be at least somewhat comprehensible to students at } \\
\text { the high school level }\end{array}$ \\
\hline Montana & B & $\mathrm{C}$ & No human evolution. Historical connection is lacking \\
\hline Nebraska & $\mathrm{C}$ & $\mathrm{C}$ & $\begin{array}{l}\text { Weak on evolution; includes creationist jargon- the word "theory" is used only in relation to } \\
\text { biological evolution }\end{array}$ \\
\hline Nevada & $\mathrm{C}$ & $\mathrm{C}$ & No human evolution \\
\hline
\end{tabular}


Table 1 (continued)

\begin{tabular}{|c|c|c|c|}
\hline State & $\begin{array}{l}\text { Grade Lerner } \\
(2000)\end{array}$ & $\begin{array}{l}\text { Current } \\
\text { Grade } 2009\end{array}$ & Description and/or general comments. \\
\hline $\begin{array}{l}\text { New } \\
\text { Hampshire }\end{array}$ & $\mathrm{F}$ & A & Improved treatment of evolution; human evolution included \\
\hline New Jersey & A & A & Thorough and explicit treatment of evolution \\
\hline New Mexico & $\mathrm{C}$ & A & Good across the board \\
\hline New York & $\mathrm{C}$ & $\mathrm{C}$ & No revision since 1996. Lerner 2000 indicated some unintentional creationist jargon \\
\hline $\begin{array}{l}\text { North } \\
\text { Carolina }\end{array}$ & A & $\mathrm{B}$ & $\begin{array}{l}\text { Treatment of both biological and human evolution is good. Inadvertent use of evolution- } \\
\text { weakening terminology (i.e. change over time) in middle school }\end{array}$ \\
\hline North Dakota & $\mathrm{F}$ & $\mathrm{C}$ & Improved. Discusses both geological and cosmological evolution explicitly in high school \\
\hline Ohio & $\mathrm{F}$ & $\mathrm{B}$ & Generally good \\
\hline Oklahoma & $\mathrm{F}$ & $\mathrm{F}$ & The word "evolution" is never used \\
\hline Oregon & $\mathrm{B}$ & $\mathrm{B}$ & No human evolution \\
\hline Pennsylvania & A & A & Good across the board \\
\hline Rhode Island & A & $\mathrm{B}$ & Generally good. Geological evolution and cosmology could be introduced earlier \\
\hline $\begin{array}{l}\text { South } \\
\text { Carolina }\end{array}$ & A & A & Very limited coverage of human evolution \\
\hline South Dakota & $\mathrm{B}$ & $\mathrm{C}$ & Adequate treatment of biological evolution. No human evolution \\
\hline Tennessee & $\mathrm{F}$ & $\mathrm{D}$ & Improved treatment of evolution. No human evolution \\
\hline Texas & $\mathrm{C}$ & $\mathrm{F}$ & Generally comprehensive except for creationist jargon \\
\hline Utah & $\mathrm{B}$ & $\mathrm{B}$ & No human evolution \\
\hline Vermont & $\mathrm{B}$ & $\mathrm{B}$ & Good treatment of biological evolution. No human evolution \\
\hline Virginia & $\mathrm{D}$ & $\mathrm{C}$ & No human evolution \\
\hline Washington & $\mathrm{B}$ & $\mathrm{B}$ & Explicit mention of cosmological evolution by high school \\
\hline West Virginia & $\mathrm{F}$ & $\mathrm{F}$ & Improvement on treatment of biological evolution. No human evolution. \\
\hline Wisconsin & $\mathrm{D}$ & $\mathrm{D}$ & Offer only performance standards for grades 4,8 , and 12 and clear standards are lacking \\
\hline Wyoming & $\mathrm{F}$ & $\mathrm{D}$ & Improved presentation of biological evolution. No human evolution \\
\hline
\end{tabular}

cosmology, which, if mentioned, is often left to high school. We found that many states introduce students to the earth, solar system, and even universe early on but do not reference the Big Bang as the current scientific theory for the origin of the universe. Discussion of the connection between biological, geological, and cosmological systems also varied across states; only 17 states provided a comprehensive treatment.

In addition to scoring and grading each set of state standards, a few states merit further discussion, particularly because they provide excellent examples of the successes and failures of the standards-setting process. Florida and Kansas are stories of success. Louisiana and Texas are examples of how and where things can go very wrong and the implications for teachers. Hawaii provides an example of how even a failed antievolution campaign can do subtle damage to science standards. Finally, we draw attention to Minnesota and Colorado - two states currently revising standards.

Florida Over the past decade, Florida has improved its standards more dramatically than perhaps any other state. The 1999 standards received an F from Lerner (2000) for their (lack of) treatment of biological and geological evolution and scored zero in the Fordham Foundation's 2005 report, "The State of State Science Standards." As both reports observed, evolution was not even mentioned by name at the time. However, after several months of public discussion and debate, the Florida Department of Education's writing committee developed a vastly superior set of standards in 2007. Biological evolution became prominent, human evolution was explicitly discussed, and geological and cosmological evolution were covered as well. In February 2008, after fierce creationist opposition, the Board of Education approved a revised version in which evolution was persistently referred to as "the scientific theory of evolution." A similar label was used for plate tectonics, cell theory, atomic theory, and electromagnetism (this tactic of protecting creationist-opposed topics by textually grouping them with less "offensive" areas of science, in order to imply that all are equally legitimate, is also used in the Minnesota standards; we discuss below why we believe it may be largely ineffective). However, the standards also explicitly required that students be able to "recognize and explain that a scientific theory is a well- 


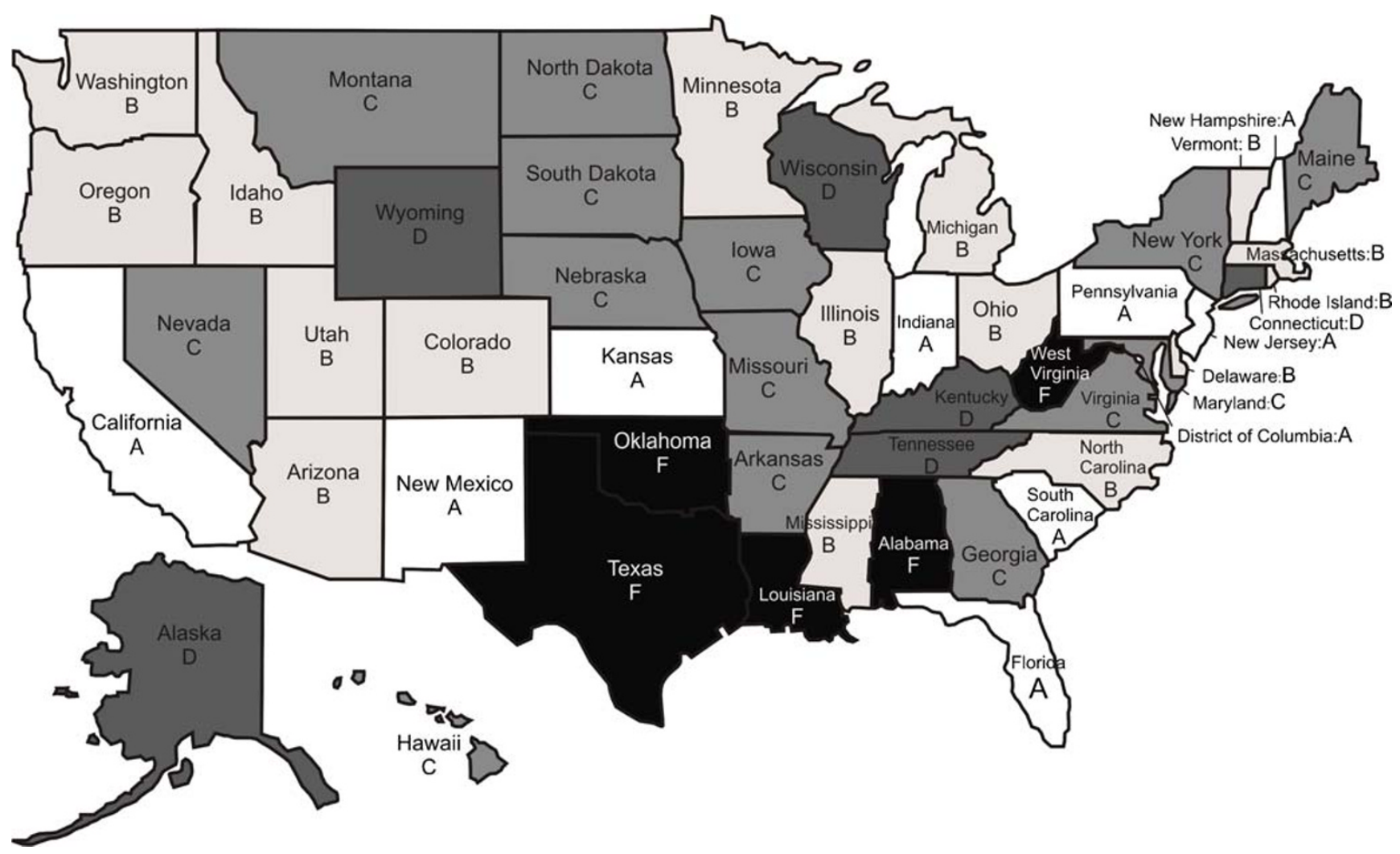

Fig. 1 Grades of 50 states and the District of Columbia evaluated on the inclusion of evolution in state science standards

supported and widely accepted explanation of nature and is not simply a claim posed by an individual. Thus, the use of the term theory in science is very different than how it is used in everyday life." This does an excellent job of heading off "just a theory"-style attacks on evolution, and Florida's current standards score a solid A.

Kansas No state illustrates the political vulnerability of science education more clearly than Kansas; the Kansas standards have seesawed between abysmal and excellent no fewer than four times in the last decade. In 1999, a creationist majority on the Board of Education systematically eliminated nearly every mention of biological, geological, and cosmological evolution from the standards, every reference to the age of the earth or universe, and even indirectly related material such as radiometric dating methods. Unsurprisingly, Lerner (2000) failed Kansas, calling their standards a "disgraceful paean to antiscience." The public responded by ousting three supporters of the change, and in 2001, a largely new Board voted to restore evolution to the standards. However, a creationist majority returned to the Board in 2004 and, in 2005, approved a new set of standards. This time, the Board did not eliminate evolution but, rather, added a large amount of antievolution material themed around intelligent design. This included redefining science so as not to depend on "natural explanations," characterizing evolution in particular as depending on an "unguided natural process," attacking common descent, gradualism and abiogenesis, and invoking the ID concept of "irreducible complexity." The makeup of the Board shifted again in 2006, to a proscience majority, and the current standards were approved in early 2007. These are excellent overall, easily earning an A. Given Kansas' history, we should be prepared for them to be altered again in the future. In each past episode, the combined efforts of activists, scientists', and educators' organizations at the local, state, and national levels were crucial to restoring good science standards, and doubtless, they will be again.

Louisiana The coverage of evolution in Louisiana's state science standards is actually adequate and would have received a grade of $\mathrm{C}$ but for the Louisiana Science Education Act. Following the passing of the Louisiana Science Education Act, the Louisiana Board of Elementary and Secondary Education (BESE) was ordered to establish science education guidelines consonant with this act. These guidelines, passed in January 2009, state that BESE is to provide "support and guidance of teachers regarding effective ways to understand, analyze, critique, and objectively review concepts, laws, principles, and scientific theories." To this end, teachers are permitted to use 
"supplemental textbooks and other instructional materials," save for those prohibited by BESE after a lengthy and onerous review process. The Louisiana Department of Education proposed that these guidelines forbid "materials that teach creationism or intelligent design or that advance the religious belief that a supernatural being created humankind," but BESE removed this caveat after objections by creationist organizations and the sponsor of the LSEA. The brief but adequate treatment of evolution in the state science standards is completely undermined by the LSEA, and the standards now score an F.

Texas Starting in 1998, Process Skill 3A was added to the TEKS, stating that students were expected to "analyze, review, and critique scientific explanations including hypotheses and theories, as to their strengths and weaknesses using scientific evidence and information." Texas was awarded a score of $\mathrm{C}$ by Lerner in 2000, who described its standards as "brief but satisfactory." In 2008-2009, the standards were heavily revised, and $3 \mathrm{~A}$ was removed by the Department of Education's scientific advisory committees. Creationists on the Board of Education attempted unsuccessfully to replace this language but did add many other pieces of creationist jargon, including:

- "in all fields of science, analyze, evaluate, and critique scientific explanations by using empirical evidence, logical reasoning, and experimental and observational testing, including examining all sides of scientific evidence of those scientific explanations, so as to encourage critical thinking by the student;"' (The revised Process Skill 3A, for all scientific subjects)

- "analyze and evaluate scientific explanations concerning any data of sudden appearance, stasis, and sequential nature of groups in the fossil record;" (7A, for Biology)

- "analyze and evaluate scientific explanations concerning the complexity of the cell;" (7G, for Biology)

- "analyze and evaluate the evidence regarding formation of simple organic molecules and their organization into long complex molecules having information such as the DNA molecule for self-replicating life;" (9D, for Biology)

- "analyze and evaluate a variety of fossil types such as transitional fossils, proposed transitional fossils, fossil lineages, and significant fossil deposits with regard to their appearance, completeness, and alignment with scientific explanations in light of this fossil data;" (4A, for Earth and Space Science)

- "evaluate the evidence concerning the Big Bang model such as red shift and cosmic microwave background radiation and current theories of the evolution of the universe, including estimates for the age of the universe." (8A, for Earth and Space Science)
Notably, in the last standard mentioned, the Board removed a statement that the estimated age of the universe was 14 billion years; then-chairman Don McLeroy is a young-earth creationist who has stated that the Earth is about 6,000 years old. Given the loss and adulteration of content in the areas of cosmological and geological evolution and the profusion of creationist jargon, we cannot score Texas' current standards as other than an F.

Hawaii The Earth/Space Science standard, circa 2007, directs the student to "compare different theories concerning the formation of the universe." Its sample performance standard elaborates, "The student: Compares the Big Bang Theory to another theory of the origin of the universe (includes supporting evidence for both theories and evidence that refutes the theories) and recommends which theory is more plausible." A casual observer might view this reference to "another theory" as pointless but harmless; however, in an older (1999) science standards document, which is still available on the website of the Hawaii Department of Education with no indication of obsolescence, the glossary contains the entry "Evolution vs. creation: two approaches to help explain the origin of life; the former based on Darwin's Theory of Evolution and the latter on divine intervention." In 2001 the Hawaii State Board of Education debated whether to insert creationist language (invoking "multiple theories of origin") into the section of the standards discussing evolution. This language was defeated, but we suggest that the above reference to "another theory of the origin of the universe" is a holdover from this earlier attempt to accommodate creationists.

Minnesota Minnesota's standards have just been approved by the Minnesota Department of Education and are currently going through the legislative process for formal implementation. They earn a score of B, as they did in 2000, but this masks significant improvement; in particular, biological evolution is covered more thoroughly than it was before. Two problems prevent their score from rising from a high $\mathrm{B}$ to an A: Their coverage of cosmological evolution is nonexistent before the high school level, and they contain some creationist jargon, specifically the benchmark 9.1.1.7: "Explain how scientific and technological innovations -as well as new evidence can challenge portions of, or entire accepted theories and models including, but not limited to: cell theory, atomic theory, theory of evolution, plate tectonic theory, germ theory of disease, and the big bang theory." Minnesota science education advocates believe that this long-standing benchmark was not written by creationists but was presented as a compromise to forestall even worse "evidence against evolution" language. Thus, the 
benchmark is meant to imply that evolution, Big Bang theory and plate tectonic theory are just as well supported by evidence as cell theory, atomic theory and germ theory and that while evidence-based "challenges" to the former theories are not impossible, they are no more likely than valid challenges to the latter. However, students do not learn directly from this benchmark or from any other standard but rather from lessons and teaching materials permitted by the standards. This benchmark permits and indeed encourages creationist materials, which cast doubt on biological, geological and cosmological evolution. It is likely that creationist activists will push for these materials to be taught and will simply pay no attention to the part of the benchmark that refers to other theories. We therefore consider it to be a mild example of creationist jargon, as we define the term above, and we recommend that Minnesota educators and science advocates continue to watch their schools for signs of its abuse. Other than this issue and the lack of cosmological material in earlier grades, Minnesota's standards are excellent.

Colorado Colorado's academic standards are currently undergoing overhaul; a draft of its science standards was released on May 1 for public comment. The science standards also earn a score of B, as they did in 2000 . While mostly solid, Colorado continues to treat human evolution only implicitly, through broad statements such as, "Organisms are classified into a hierarchy of groups and subgroups based on similarities which reflect their evolutionary relationships" (Standard 3,
Benchmark 14 for grades 9-12). It also makes no mention of the Big Bang whatsoever nor does it otherwise discuss the age and development of the universe. Lerner (2000) comments that Colorado received a D overall in the Thomas B. Fordham Institute's The State of State Standards 2000, "mainly on the basis of its poor treatment of the physical sciences"; the lack of cosmological material may reflect this more general weakness. Colorado's standards will be approved by the State Board of Education in December 2009; we encourage Colorado educators and interested citizens to follow the review and approval process at the Department of Education's webpage. (http://www.cde.state. co.us/cdeassess/UAS/standardsreview.html). Questions and feedback can also be sent to the review committee staff at the Colorado Standards Review Home webpage. (http://colorado standards review.wetpaint.com/).

\section{Recommendations}

Get involved. Check to see when your state is next reviewing state standards, and ask your department of education or state educators' associations how to participate in that process. Take a careful look at the language of your standards; check not only for explicit creationist claims but also for language that permits or encourages teaching material that makes such claims. Do not confine your attention to life science courses; check whether earth and space science courses discuss

\section{Appendix}

Table 2 State scores for the coverage of various aspects of evolution in state science standards

\begin{tabular}{|c|c|c|c|c|c|c|c|c|c|c|c|}
\hline State & $\begin{array}{l}\text { E- } \\
\text { word }\end{array}$ & $\begin{array}{l}\text { Biological } \\
\text { evolution }\end{array}$ & $\begin{array}{l}\text { Human } \\
\text { evolution }\end{array}$ & $\begin{array}{l}\text { Geological } \\
\text { evolution }\end{array}$ & $\begin{array}{l}\text { Cosmological } \\
\text { evolution }\end{array}$ & $\begin{array}{l}\text { Historical } \\
\text { sciences }\end{array}$ & $\begin{array}{l}\text { Creationist } \\
\text { jargon }\end{array}$ & Disclaimers & $\begin{array}{l}\text { Raw } \\
\text { score }\end{array}$ & Percentage & Grade \\
\hline $\mathrm{AL}$ & 5 & 10 & 0 & 20 & 10 & 2.5 & 0 & -25 & 22.5 & 20.5 & $\mathrm{~F}$ \\
\hline AK & 20 & 30 & 0 & 10 & 5 & 0 & 0 & 0 & 65 & 59.1 & $\mathrm{D}$ \\
\hline $\mathrm{AZ}$ & 20 & 30 & 0 & 20 & 10 & 10 & 0 & 0 & 90 & 81.8 & B \\
\hline AR & 20 & 30 & 0 & 20 & 0 & 2.5 & 0 & 0 & 72.5 & 65.9 & $\mathrm{C}$ \\
\hline $\mathrm{CA}$ & 20 & 40 & 10 & 20 & 10 & 10 & 0 & 0 & 110 & 100 & A \\
\hline $\mathrm{CO}$ & 20 & 40 & 2.5 & 20 & 2.5 & 5 & 0 & 0 & 90 & 81.8 & B \\
\hline $\mathrm{CT}$ & 20 & 30 & 0 & 10 & 5 & 0 & 0 & 0 & 65 & 59.1 & $\mathrm{D}$ \\
\hline $\mathrm{DE}$ & 20 & 40 & 0 & 20 & 5 & 2.5 & 0 & 0 & 87.5 & 79.5 & B \\
\hline DC & 20 & 40 & 10 & 20 & 5 & 10 & 0 & 0 & 105 & 95.5 & A \\
\hline $\mathrm{FL}^{\mathrm{a}}$ & 20 & 40 & 10 & 20 & 5 & 5 & 0 & 0 & 100 & 90.9 & A \\
\hline GA & 10 & 20 & 2.5 & 20 & 10 & 10 & 0 & 0 & 72.5 & 65.9 & $\mathrm{C}$ \\
\hline HI & 20 & 40 & 2.5 & 20 & 5 & 5 & -10 & 0 & 82.5 & 75 & $\mathrm{C}$ \\
\hline ID & 20 & 30 & 0 & 20 & 10 & 10 & 0 & 0 & 90 & 81.8 & B \\
\hline IL & 20 & 30 & 10 & 10 & 10 & 10 & 0 & 0 & 90 & 81.8 & B \\
\hline
\end{tabular}


Table 2 (continued)

\begin{tabular}{|c|c|c|c|c|c|c|c|c|c|c|c|}
\hline State & $\begin{array}{l}\text { E- } \\
\text { word }\end{array}$ & $\begin{array}{l}\text { Biological } \\
\text { evolution }\end{array}$ & $\begin{array}{l}\text { Human } \\
\text { evolution }\end{array}$ & $\begin{array}{l}\text { Geological } \\
\text { evolution }\end{array}$ & $\begin{array}{l}\text { Cosmological } \\
\text { evolution }\end{array}$ & $\begin{array}{l}\text { Historical } \\
\text { sciences }\end{array}$ & $\begin{array}{l}\text { Creationist } \\
\text { jargon }\end{array}$ & Disclaimers & $\begin{array}{l}\text { Raw } \\
\text { score }\end{array}$ & Percentage & Grade \\
\hline IN & 20 & 40 & 10 & 20 & 5 & 10 & 0 & 0 & 105 & 95.5 & A \\
\hline IA & 20 & 30 & 0 & 20 & 5 & 10 & 0 & 0 & 85 & 77.3 & $\mathrm{C}$ \\
\hline KS & 20 & 40 & 5 & 20 & 10 & 10 & 0 & 0 & 105 & 95.5 & A \\
\hline KY & 5 & 20 & 0 & 20 & 5 & 10 & 0 & 0 & 60 & 54.5 & $\mathrm{D}$ \\
\hline LA & 20 & 30 & 0 & 20 & 5 & 5 & -25 & -25 & 30 & 27.3 & $\mathrm{~F}$ \\
\hline $\mathrm{ME}$ & 20 & 40 & 0 & 10 & 2.5 & 2.5 & 0 & 0 & 75 & 68.2 & $\mathrm{C}$ \\
\hline MD & 20 & 30 & 0 & 20 & 5 & 5 & 0 & 0 & 80 & 72.7 & $\mathrm{C}$ \\
\hline MA & 20 & 40 & 2.5 & 20 & 5 & 5 & 0 & 0 & 92.5 & 84.1 & B \\
\hline MI & 20 & 30 & 10 & 20 & 5 & 2.5 & 0 & 0 & 87.5 & 79.5 & B \\
\hline $\mathrm{MN}$ & 20 & 40 & 5 & 20 & 5 & 10 & -2.5 & 0 & 97.5 & 88.6 & B \\
\hline MS & 20 & 40 & 2.5 & 20 & 10 & 5 & -2.5 & 0 & 95 & 86.4 & B \\
\hline MO & 20 & 40 & 0 & 20 & 5 & 10 & -10 & 0 & 85 & 77.5 & $\mathrm{C}$ \\
\hline MT & 20 & 30 & 0 & 20 & 10 & 2.5 & 0 & 0 & 82.5 & 75.0 & $\mathrm{C}$ \\
\hline $\mathrm{NE}$ & 20 & 30 & 5 & 10 & 5 & 5 & -2.5 & 0 & 72.5 & 65.9 & $\mathrm{C}$ \\
\hline NV & 20 & 40 & 0 & 10 & 10 & 5 & 0 & 0 & 85 & 77.3 & $\mathrm{C}$ \\
\hline NH & 20 & 40 & 5 & 20 & 5 & 10 & 0 & 0 & 100 & 90.9 & A \\
\hline NJ & 20 & 40 & 10 & 20 & 10 & 10 & 0 & 0 & 110 & 100 & A \\
\hline NM & 20 & 40 & 5 & 20 & 5 & 10 & 0 & 0 & 100 & 90.9 & A \\
\hline NY & 20 & 30 & 5 & 5 & 10 & 10 & -5 & 0 & 75 & 68.5 & $\mathrm{C}$ \\
\hline $\mathrm{NC}$ & 20 & 40 & 5 & 20 & 5 & 10 & -10 & 0 & 90 & 81.8 & B \\
\hline ND & 20 & 30 & 0 & 10 & 5 & 5 & 0 & 0 & 70 & 63.6 & $\mathrm{C}$ \\
\hline $\mathrm{OH}$ & 20 & 40 & 5 & 10 & 10 & 10 & 0 & 0 & 95 & 86.4 & B \\
\hline OK & 0 & 20 & 0 & 5 & 2.5 & 0 & 0 & 0 & 27.5 & 25.0 & $\mathrm{~F}$ \\
\hline OR & 20 & 30 & 0 & 20 & 10 & 10 & 0 & 0 & 90 & 81.8 & B \\
\hline PA & 20 & 40 & 10 & 20 & 10 & 5 & 0 & 0 & 105 & 95.5 & A \\
\hline RI & 20 & 40 & 10 & 10 & 5 & 5 & 0 & 0 & 90 & 81.8 & B \\
\hline $\mathrm{SC}$ & 20 & 40 & 0 & 20 & 10 & 10 & 0 & 0 & 100 & 90.9 & A \\
\hline SD & 20 & 30 & 0 & 20 & 10 & 5 & 0 & 0 & 85 & 77.3 & $\mathrm{C}$ \\
\hline $\mathrm{TN}$ & 10 & 30 & 0 & 10 & 5 & 5 & 0 & 0 & 60 & 54.5 & $\mathrm{D}$ \\
\hline $\mathrm{TX}$ & 20 & 30 & 0 & 10 & 5 & 5 & -20 & 0 & 50 & 45.5 & $\mathrm{~F}$ \\
\hline UT & 20 & 30 & 0 & 20 & 10 & 10 & 0 & 0 & 90 & 81.8 & B \\
\hline VT & 20 & 30 & 5 & 20 & 10 & 10 & 0 & 0 & 95 & 86.4 & B \\
\hline VA & 10 & 30 & 0 & 20 & 10 & 5 & 0 & 0 & 75 & 68.2 & $\mathrm{C}$ \\
\hline WA & 20 & 40 & 5 & 20 & 5 & 5 & 0 & 0 & 95 & 86.4 & B \\
\hline WV & 10 & 30 & 0 & 5 & 5 & 0 & 0 & 0 & 50 & 45.5 & $\mathrm{~F}$ \\
\hline WI & 20 & 30 & 0 & 10 & 5 & 5 & 0 & 0 & 70 & 63.6 & $\mathrm{D}$ \\
\hline WY & 20 & 30 & 0 & 10 & 5 & 2.5 & 0 & 0 & 67.5 & 61.4 & D \\
\hline
\end{tabular}

${ }^{a}$ Values for Florida were taken from a report Lawrence Lerner provided the National Center for Science Education

Criteria used for scoring treatment of evolution (as described in Lerner 2000)

Column 2: "E-word used?"

20: The word "evolution" is used whenever called for. There are likely one or more major sections entitled "Evolution"

10: The word is used, but not often. It may well appear more frequently in earth science or astronomy sections than in life-science sections

5: The word is used just once, or appears only in one or a few places where it might easily be missed

0 :The word does not appear

Column 3: "Biological evolution treated?"

40: The treatment is thorough and detailed and permeates the treatment of the historical sciences rather than being confined to a single section. At least some of the basic underlying concepts essential to understanding evolution are introduced at early grades 
30: Evolution is treated straightforwardly but perhaps briefly and/or not in the earlier grades. The overarching importance of evolution, especially in the life sciences, is not stressed

20: Evolution is mentioned briefly but the criteria for higher scores are not met

10: Evolution is mentioned, but not in a way that encourages clarification of its role in the life sciences

0 : No treatment

Column 4: "Human evolution treated?"

10: There is at least some direct mention of human evolution

5: Human evolution is not mentioned explicitly, but is implied in statements to the effect that biological concepts are as applicable to humans as to other animals

2.5 Human evolution is very weakly implied

0 : No treatment of human evolution

Column 5: "Geological evolution treated?"

20: Substantial attention is devoted to the history of the earth and to such mechanisms as plate tectonics and continental drift, usually at early or middle grades

10: The treatment of earth history is good but less than ideally thorough, with treatment usually beginning at the middle or even high school level

5: Words such as "plate tectonics" and "continental drift" are used, but in a limited way and/or at the high school level only

2.5 Mention only in passing, at the high-school level only

0 : No treatment

Column 6: "Cosmology treated?"

10: There is significant discussion of the Big Bang, of stellar evolution, of the Hertzsprung-Russell diagram, and perhaps of quasars, neutron stars, black holes, and other cosmologically significant objects, usually beginning at the middle-school or even the primary level

5: There is a brief treatment, usually only at the high school level

2.5: There is a single statement, at the high school level, of the form "Students will be able to discuss the Big Bang and other theories of the origin of the universe"

0: No treatment

"Column 7: Connections among the historical sciences treated?"

10: Significant exposition of the seamless connection among the life, earth, and space sciences. Examples: discussion of the essential role of living things in the transition of the earth's atmosphere from reducing to oxidizing and the consequences of this for the evolution of life; the use of radioactive dating in geology and biology; the presence of iridium at the K-T boundary. These ideas are typically introduced in the middle or early grades

5: Brief treatment with few examples, usually confined to the upper grades

2.5: Minimal treatment

0 : No treatment

Column 8: "Creationist jargon used?"

States that use creationist jargon lose points; they are docked for undermining the sound treatment of evolution

-20: Extensive use of the kinds of language used by creationists to cast doubt on the theory of evolution: for instance, describing evolution as a controversial theory among scientists, conflating the scientific meaning of the word "theory" with its everyday meaning, and misusing the term "microevolution" to describe known examples of evolution that result in diverse species

-10 Less extensive use of such terminology

-5 : Brief, probably inadvertent use of the terminology

0 : No use

Column 9: "Disclaimer?"

States that require a disclaimer lose points; they are docked for subverting the sound treatment of evolution

-25 Yes. The state requires a statement that attempts to deny what its textbooks are teaching

0 : No use 
Table 3 Documents reviewed for analysis of evolution in state science standards

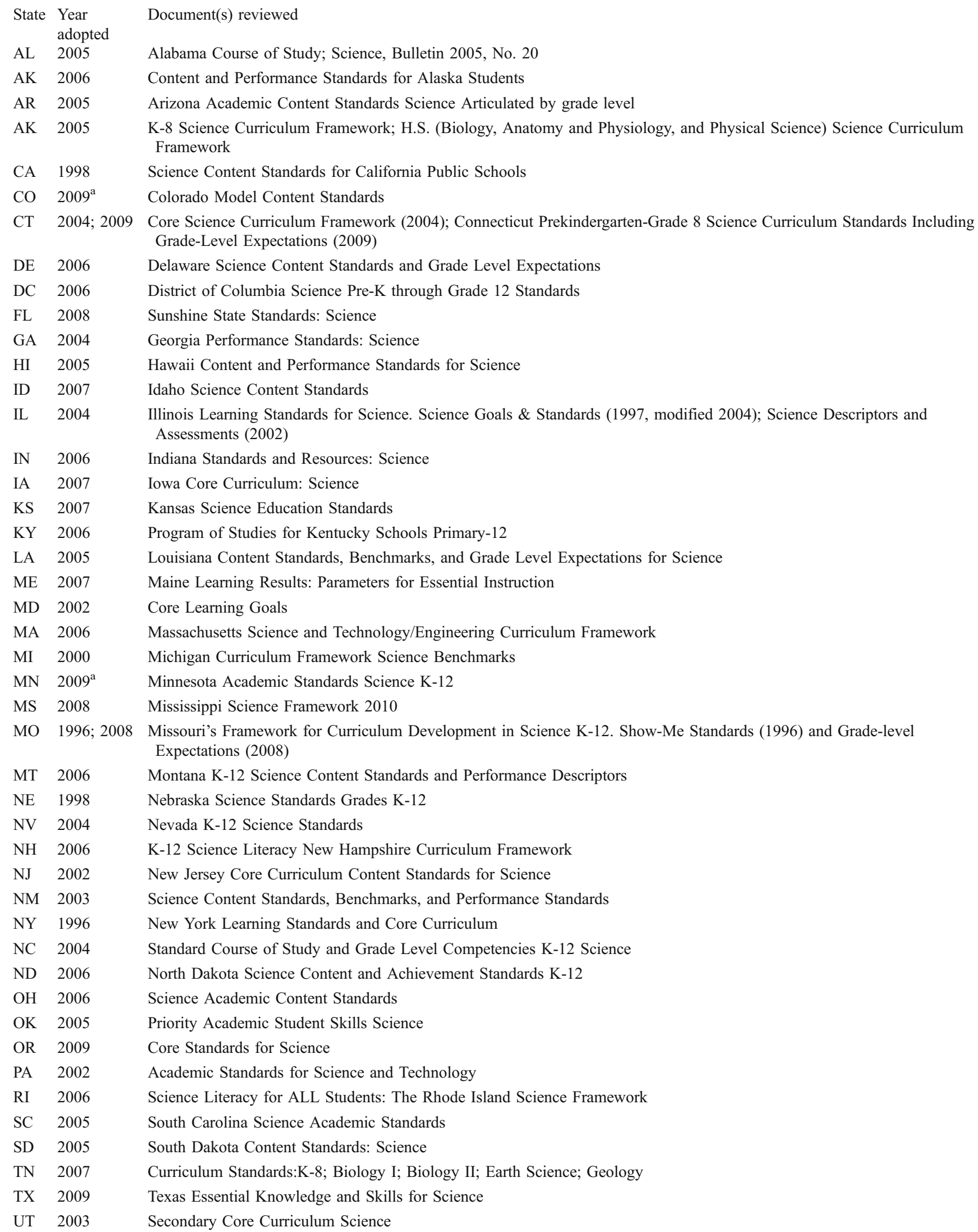




$\begin{array}{lll}\text { VT } & 2000 & \text { Vermont's Framework of Standards and Learning Opportunities } \\ \text { VA } & 2003 & \text { Science Standards of Learning for Virginia's Public Schools } \\ \text { WA } & 2005 & \text { Essential Academic Learning Requirements; K-10 Grade Level Expectations Science } \\ \text { WV } & 2008 & \text { 21st Century Science 9-12 Content Standards and Objectives for West Virginia Schools } \\ \text { WI } & 1998 & \text { Model Academic Standards for Science } \\ \text { WY } & 2003 & \text { Wyoming Science Content and Performance Standards }\end{array}$

${ }^{a}$ State standards currently in revision process

cosmological and geological evolution and whether human evolution is discussed in social studies or anatomy courses (as is sometimes the case). And make sure that the groundwork for all of these subjects is laid in $\mathrm{K}-8$, rather than introduced for the first time in high school.

\section{References}

Branch G, Scott EC. The latest face of creationism. Sci Am. 2009;300 (1):92-9.

Braden L, Finn CE, Lerner LS, Munroe S, Petrilli MJ, Raimi RA, Saxe DW, Smith T, Stotsky S. The State of State Standards. Washington: Thomas Fordham Foundation; 2000.

Gross PR, Goodenough E, Haack S, Lerner L, Schwartz M, Schwartz R. The state of state science standards. Washington: Thomas B. Fordham Institute; 2005.

Johnson GB, Raven PH. Holt biology (Texas teacher edition). Austin: Holt, Rinehart, and Winston; 2004.

Lerner L. Good Science, Bad Science: Teaching Evolution in the States. Washington: Thomas Fordham Foundation; 2000.
Moore R. Teaching Evolution: Do State Science Standards Matter? Reports of the National Center for Science Education. 2009;21 (1-2):19-21.

Rosenau J. Implementing Louisiana's anti-evolution law. Reports of the National Center for Science Education. 2009;29(2):5-7.

Scott EC, Branch G. The OOPSIE compromise-A big mistake. Evolution: Education and Outreach. 2008;1(2):147-9.

Simon S. 2009. Texas opens classroom door for evolution doubts. The Wall Street Journal; March 7: A3. http://online.wsj.com/article/ SB123819751472561761.html.

Skoog G, Bilica K. The emphasis given to evolution in state science standards: a lever for change in evolution education? Sci Educ. 2002;86:445-62.

Swanson, C. 2005. Evolution in State Science Education Standards. http://www.edweek.org/media/epe_evolution1105.pdf

National Research Council. National Science Education Standards. Washington: National Academy Press; 1996.

The National Commission on Excellence in Education. A Nation at Risk: The Imperative for Educational Reform, 1983

American Association for the Advancement of Science. Science for All Americans: Education for a changing future. Oxford: Oxford University Press, 1989.

American Association for the Advancement of Science. Benchmarks for Science Literacy. Oxford: Oxford University Press, 1993. 